\title{
APRESENTAÇÃO
}

\section{Diálogos Intermediais do Texto PoÉtico}

O alargamento das fronteiras conceituais, teóricas e metodológicas dos estudos naárea de Letras no Brasile no mundo-e, mais especificamente, no que tange a pesquisas sobre a poesia e o poema - tem sido objeto de discussões em eventos e publicações especializadas, os quais apontam os benefícios e os desafios de tal expansão do campo. Entre diversos fatores sociais, políticos e epistemológicos que condicionam essas transformações na área, cumpre aqui ressaltar uma virada - ou, melhor, uma ampliação do foco no texto para uma atenção à materialidade sobre a qual este se constitui. Em vez de uma simplista oposição entre a virtualidade textual e a realização midiática, o que os estudos mais recentes apontam é uma indissociabilidade dessas dimensões analíticas, entre as quais se estabelece uma dialética que precisa ser considerada por pesquisadores a fim de melhor compreender os fenômenos literários.

Sob tal perspectiva, cumpre ressaltar que é da natureza do fenômeno poético o questionamento das fronteiras de sua expressão, seja no plano dos sistemas de signos, seja nas materialidades em que estes se constroem. Os diálogos entre diferentes linguagens e diferentes mídias compõem, pois, parte significativa dos exercícios líricos e de suas releituras em praticamente todas as épocas e espaços, o que mantém sempre atuais e relevantes os estudos sobre as relações intersemióticas estabelecidas pela poesia - objeto de estudo que orienta os trabalhos da Texto Poético.

Diante de tal contexto, os organizadores do número 29 deste periódico propuseram a presente chamada para um dossiê intitulado Diálogos Intermediais do Texto Poético, que visava congregar trabalhos que tematizassem, entre outras possibilidades de objetos, os (des) encontros entre poesia e artes plásticas, poesia e audiovisual, poesia e performance, poesia eletrônica e digital, em meio a tantas outras dinâmicas de ressignificação do lírico em vetores para outras mídias. 
Desse modo, o objetivo - realizado a contento na edição ora apresentada - era compor um volume cujos artigos atentassem para jogos de intertextualidade, intermedialidade, remediatização, iconicidade, ekphrasis e experimentalismos interartes. O produto deste trabalho é aqui apresentado na forma de cinco textos publicados no dossiê, em que se destacam os diálogos intermediais entre produtos artísticos criados nos séculos XX e XXI em países como Brasil, Portugal, França e Itália. Junto a eles, são também aqui publicados três artigos na seção "Vária", que, em todos os números do periódico, reúne textos analíticos que resultam de projetos de pesquisa sobre temáticas concernentes à poesia e ao poema.

Abrindo o dossiê, A poesia mastiga o filme: o cinema na poesia ecfrástica de João Miguel Fernandes Jorge e Manuel Gusmão, de Patrícia Resende Pereira, discute as diferentes formas como cinema e poesia se entrelaçam no trabalho lírico dos escritores portugueses. Para tanto, é tomado por principal operador de leitura o conceito da écfrase, em suas diferentes acepções, com vistas à análise de como poemas de João Miguel Fernandes Jorge e Manuel Gusmão constroem releituras de objetos artísticos fílmicos (destacadamente, A palavra, dirigido por Carl T. Dreyer, e Rosetta, dirigido por Jean-Pierre Dardenne e Luc Dardenne). Como vetor comum aos procedimentos de ambos os poetas, o artigo indica a subjetividade que orienta o ato de criação, que não se limita à transposição verbal dos elementos figurados imageticamente nas películas.

Também em Gabriele D’Annunzio e a edição ilustrada de Francesca da Rimini (1902), de Fabiano Dalla Bona, ganham destaque as relações entre palavra e imagem, mas agora em releituras de um dos mitos mais longevos da cultura ocidental: Francesca da Rimini. O artigo traça um breve perfil desse topos (que inclui poemas, comédias, tragédias, melodramas, pinturas, esculturas, gravuras) e analisa a relação entre literatura e artes visuais na edição de luxo de Gabriele D’Annunzio, publicada em 1902 e ilustrada por Adolfo De Carolis. A análise baseia-se em uma detalhada leitura da correspondência entre o escritor e o ilustrador, De Carolis, ensejando uma reflexão da colaboração intermedial de ambos, além de convidar à apreciação crítica de imagens extraídas da obra. 
A hibridização entre diferentes linguagens e/ou campos do saber é também tema central de A aura murchada de Eduardo Kac: raízes em Benjamin, em que Daniel de Oliveira Gomes investiga a obra Edunia, do poeta experimental Eduardo Kac, definido no texto como um "híbrido poeta-petúnia”. Em sua argumentação, o artigo alude ao clássico texto de Walter Benjamin, A obra de arte na era de sua reprodutibilidade técnica, bem como a poetas canônicos que tematizam a imagem da flor moderna, tais como Baudelaire e Drummond, a fim de analisar o projeto de Kac, que combina intervenção poética e engenharia genética, em um gênero também conhecido como "bioarte".

Da ciência à tecnologia, outros diálogos intermediais com o texto poético são propostos em CAPTCHA dissolve a noite: Considerações sobre a poética do íntimo desabrigo de Tarso de Melo. Neste artigo, de Diana Junkes, propõe-se uma leitura do poema CAPTCHA, publicado em Alguns Rastros (2018). A análise investiga as tensões entre o humano e o digital estabelecidas por um eu lírico que se defronta com imagens na tela de um computador e se questiona sobre o sentido de ser e estar no mundo. Como resultado do estudo, destaca-se que, ao recuperar o tema da modernidade por excelência, tomando o poeta como um flâneur em uma sociedade altamente digitalizada, o eu poético reitera o sentimento de deslocamento e desenraizamento de um sujeito que, paradoxalmente, não sai do lugar, posto que se mantém fixo diante da tela, dissolvido na noite.

Encerrando o dossiê, ainda no bojo das discussões sobre poesia e tecnologia, Questões de poesia: inquietude e transgressão da palavra poética em espaços digitais hipermodernos, de Suzana Maria Lain Pagot, investiga os geradores automáticos de Poemas no meio do caminho, do português Rui Torres, enfocando o conceito de poesia em tempos hipermodernos. $\mathrm{O}$ artigo analisa algumas especificidades da linguagem poética a fim de averiguar como esta se articula com a mídia digital, contribuindo, dessa forma, para uma discussão do conceito de poesia digital e de suas singularidades quanto à leitura. 
Já a seção "Vária", que acolhe artigos sobre temáticas outras, mas que tenham por horizonte também as discussões sobre o texto poético, é aberta por Tempo, memória e trauma em poemas de Ferreira Gullar e Manuel Alegre, de Mariana Castelo Branco Rabelo e Marcelo Ferraz de Paula. Seu argumento se centra numa leitura comparativa dos poemas Espelho do guarda-roupa, de Ferreira Gullar, e O Cristo, de Manuel Alegre, a partir da tríade tempo, memória e trauma. O problema abordado é a crise do "dizercantar" a memória traumática com seu tempo "anômalo". Como resultado do estudo, evidencia-se que, em ambos os poemas, a linguagem poética busca em sua constituição formal mecanismos para lidar com os dilemas de representação do "real".

Na mesma seção, Pensar e escrever a partir da fronteira, de Paulo Maria Júnior e Diana Araújo Pereira, propõe, sob perspectiva descolonial, uma leitura geopoética da paisagem natural e humana na tríplice fronteira entre Brasil, Paraguai e Argentina, evidenciando em que medida tal território geográfico está também vinculado a um território simbólico e cultural, atravessado pela diversidade de línguas e sujeitos que transitam o espaço em fluxos constantes. A argumentação se orienta pela busca de uma geopoética fronteiriça que permita dar visibilidade à riqueza e à potencialidade das vozes da região.

Por fim, encerrando a seção "Vária” e o número 29 do periódico, Elvira López, seu peom e sua maeta: sobre duas cantigas satíricas de João Garcia de Guilhade, de Henrique Marques Samyn, propõe leituras para duas cantigas compostas por Guilhade sobre uma mesma personagem: "Elvira López, que mal vos sabedes"; e "Elvira López, aqui noutro dia". No artigo, os exercícios de close reading evidenciam as imagens referentes à espacialidade e à construção do gênero feminino, propondo-se ainda a seguinte questão: "que desestabilizações os deslocamentos propostos por Guilhade podem instituir, séculos depois, sobre as (nossas) subjetividades contemporâneas, enredadas em desvelar os possíveis sentidos presentes em suas cantigas?”

Diante dos supracitados trabalhos de evidente qualidade técnica e acadêmica, nós, os organizadores, convidamos a todos para que possam 
ler este número da Texto Poético e conhecer um pouco mais os resultados de pesquisas apresentados em cada um desses trabalhos. Que tenham bom proveito!

\author{
Joshua Alma Enslen ${ }^{1}$ \\ Vinícius Carvalho Pereira ${ }^{2}$ \\ (Organizadores de Dossiê)
}

1 Professor Associado e Diretor do Programa de Português em West Point. Doutor em línguas românicas da Universidade da Georgia/UGA, Athens, Georgia, Estados Unidos. Pós-doutorado do programa Materialidades da Literatura da Universidade de Coimbra/ UC, Coimbra, Portugal.

E-mail: joshua.enslen@westpoint.edu

2 Professor do Departamento de Letras e do Programa de Pós-Graduação em Estudos da Linguagem da Universidade Federal de Mato Grosso/ UFMT, Cuiabá, Mato Grosso, Brasil. Doutor e Mestre em Ciência da Literatura pela Universidade Federal do Rio de Janeiro/ UFRJ, Rio de Janeiro, Rio de Janeiro, Brasil.

E-mail para contato: viniciuscarpe@gmail.com 